OPEN ACCESS

Edited by:

Qingsong Liu,

Institute of Geology and Geophysics,

China

Reviewed by:

France Lagroix

Institut De Physique Du Globe De

Paris, France

Maodu Yan,

Institute of Tibetan Plateau Research,

China

*Correspondence:

Yongjae Yu

yongjaeyu@cnu.ac.kr

Specialty section:

This article was submitted to Geomagnetism and Paleomagnetism,

a section of the journal

Frontiers in Earth Science

Received: 11 January 2016 Accepted: 02 August 2016

Published: 17 August 2016

Citation:

Hong H, Yu Y, Doh S-J, Suk D and Kim J (2016) Magnetic Fabrics and Source Implications of Chisulryoung

Ignimbrites, South Korea.

Front. Earth Sci. 4:79

doi: 10.3389/feart.2016.00079

\section{Magnetic Fabrics and Source Implications of Chisulryoung Ignimbrites, South Korea}

\author{
Hoabin Hong ${ }^{1}$, Yongjae Yu ${ }^{1 *}$, Seong-Jae Doh ${ }^{2}$, Dongwoo Suk ${ }^{3}$ and Jeongmin Kim ${ }^{4}$ \\ ${ }^{1}$ Department of Astronomy, Space Science, and Geology, Chungnam National University, Daejeon, Korea, ${ }^{2}$ Department of \\ Earth and Environmental Sciences, Korea University, Seoul, Korea, ${ }^{3}$ Department of Marine Sciences and Convergent \\ Technology, Hanyang University, Ansan, Korea, ${ }^{4}$ Ochang Center, Korea Basic Science Institute, Cheongju, Korea
}

The anisotropy of magnetic susceptibility (AMS) of late Cretaceous ash-flow tuffs in Chisulryoung Volcanic Formation, southeastern Korea was studied to define the primary pyroclastic flow azimuth. AMS data revealed a dominant oblate fabric with a tight clustering of $k_{3}$ (minimum axis of magnetic susceptibility) and shallow dispersal of $k_{1}$ (maximum axis of magnetic susceptibility) and $k_{2}$ (intermediate axis of magnetic susceptibility). Dominance of oblate fabrics indicates clast imbrications imposed by compaction and welding. Flow azimuth inferred from AMS data indicates the nearby intrusive welded tuff (IWT) as the source of calderas for ignimbrites. Such an inference is supported by geologic investigations, in which the IWT displays eutaxitic textures nearly parallel to its subvertical contacts. The results are compatible with a unique prolate fabric and an anomalously high inclination observed for the IWT, possibly produced by rheomorphic flows as the welded tuff is squeezed along the rough-surfaced dyke walls due to agglutination.

Keywords: ignimbrites, anisotropy of magnetic susceptibility, chisulryoung, magnetic fabrics, welded tuff

\section{INTRODUCTION}

Ignimbrites are the deposits of pyroclastic density flows ejected from explosive volcanic eruptions. Ignimbrites contain volcanic glass shards, volcanic ash, pumice fragments, and lithic fragments. Loosely consolidated ignimbrites are formed when pyroclastic material is fluidized and poorly mixed due to immense explosions associated with hot volcanic ash. Instead, post depositional re-mobilization of pyroclastic material produces rheomorphic flow structures in densely welded ignimbrites. Paleomagnetic studies of ash-flow tuffs (ignimbrites) have shown that ignimbrites, whether densely welded or loosely consolidated, bear fine-grained iron oxides that can faithfully reflect an accurate record of the geomagnetic field during rapid post-emplacement cooling (e.g., Hatherton, 1954; Beck et al., 1977; Reynolds, 1977; Geissman, 1980; Geissman et al., 1983; Schlinger et al., 1986, 1988a,b, 1991; Rosenbaum, 1993; Palmer et al., 1996; Worm and Jackson, 1999; Gee et al., 2010).

The anisotropy of magnetic susceptibility (AMS) describes magnetic fabrics of rocks where AMS triaxial ellipsoids represent maximum $\left(k_{1}\right)$, intermediate $\left(k_{2}\right)$, and minimum $\left(k_{3}\right)$ susceptibility eigenvectors. AMS fabrics bear information on the current directions for sedimentary rocks, magmatic flow directions for igneous rocks, and deformational kinematics for metamorphic rocks. AMS is sensitive indicator of fabric elements within welded tuffs to yield a primary flow azimuth (Wolff et al., 1989). The fundamental basis for the successful application of AMS 
on ignimbrite relies on the physical alignment of fine-grained iron oxides within the welded tuff (Elston and Smith, 1970; Froggatt et al., 1981; Suzuki and Ui, 1982, 1983; Kamata and Mimura, 1983).

The Chisulryoung Volcanic Formation (CVF) forms an extrusive outlier $(6 \times 3 \mathrm{~km})$ around Chisulryoung Mountain (765 m), south-eastern part of the Korean peninsula. The CVF roughly forms an elliptical basin as the sedimentary rocks that underlie the CVF showed centripetal dips (Figure 1). The CVF lies within a broad structural basin regarded as a down sag caldera (Figure 1). According to Reedman et al. (1987), the CVF was produced by a sequence of subaerial explosive silicic volcanism that involved an emplacement of thick ignimbrites intercalated with volcanoclastic sedimentary rocks.

The CVF includes mainly densely to weakly welded acidic ash-flow tuffs which have been divided into four members (A1, $\mathrm{A} 2, \mathrm{~A} 3$, and A4) and three intervening volcano-sedimentary members (S1, S2, and S3) according to their crystal content, variations in volcanic clast size and type, and degree of welding (Park and Kim, 1985a,b; Park, 1990; Figure 1, Table 1). A sequence of $\mathrm{A} 1 / \mathrm{S} 1 / \mathrm{A} 2 / \mathrm{S} 2 / \mathrm{A} 3$ is the result of the first major eruptive cycle, which predates the intrusion of the
Cheogwari granodiorite (hornblende K/Ar age of $76.3 \pm 11.7$ Ma; Reedman et al., 1989). The A4 member is a product of the second eruptive cycle and S3 represents sedimentations during the interval between the two major eruptive cycles (Reedman et al., 1989; Park, 1990). The U/Pb zircon ages of $\mathrm{A} 1$ and $\mathrm{A} 4$ members are $72.8 \pm 1.7 \mathrm{Ma}$ and $67.7 \pm$ $2.1 \mathrm{Ma}$, respectively (Jeong et al., 2015). The A4 member was intruded by the Gadaeri granite (biotite K/Ar age of $63.9 \pm 1.8 \mathrm{Ma}$; Reedman et al., 1989; Table 1). An intrusive welded tuff (IWT) plug (Figure 1), with an elliptical surface exposure $(700 \times 400 \mathrm{~m})$, displays an eutaxitic texture nearly parallel to its subvertical contacts. The IWT cuts, hence it post-dates the Cheogwari granodiorite and S3. Indeed, the IWT yielded sericite K/Ar age of $65.1 \pm 1.8 \mathrm{Ma}$, statistically contemporaneous to the second eruptive cycle. In particular, Reedman et al. (1987) proposed that the IWT would be the source for the CVF.

In the present study, our main goal is to use AMS to determine flow patterns of ignimbrites for the CVF and thereby locate the source vent. When combined with other observations including petrographic description and rock magnetic measurements, the AMS data would help define the source area of the CVF. The

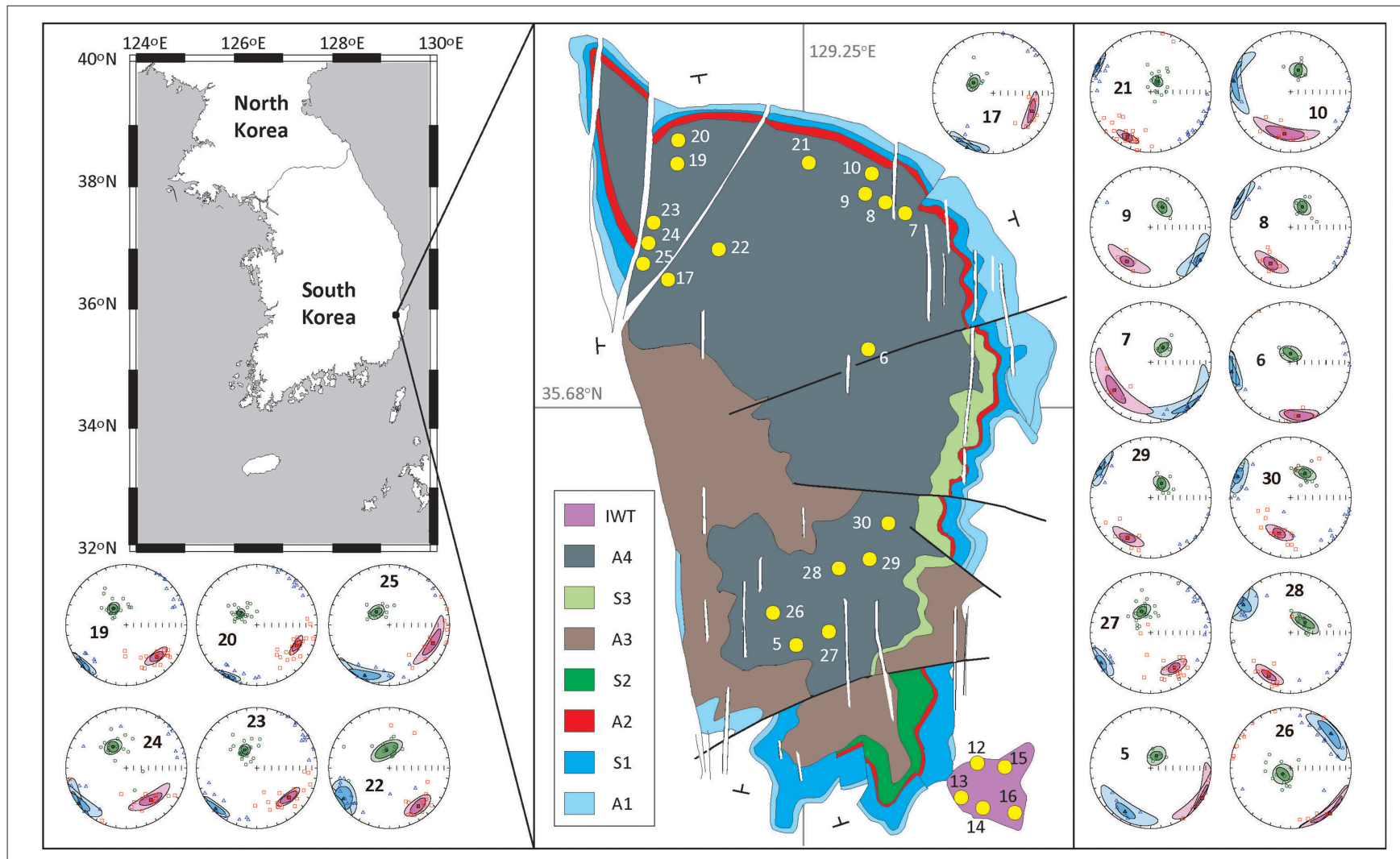

FIGURE 1 | Map of Chisulryoung Volcanic Formation (CVF) (after Park, 1990) and stereographic projections of anisotropy of magnetic susceptibility (AMS) data for $\mathbf{1 9}$ sites in A4 member. The inset was generated from the "Generic Mapping Tools (GMT)" version 5.2.1 distributed from the School of Ocean and Earth Science and Technology, University of Hawaii at Manoa (http://gmt.soest.hawaii.edu/). For each stereographic projection, eigenvectors are displayed on an equal area plot using the lower hemisphere projection with the convention that maximum $\left(k_{1}\right)$, intermediate $\left(k_{2}\right)$, and minimum $\left(k_{3}\right)$ susceptibility are represented as red squares, blue triangles, and green circles. Confidence ellipses were calculated on the basis of the Jelinek method (inner ellipses with darker colors) and the site parametric bootstrap statistics (outer ellipses with brighter colors). 
TABLE 1 | Stratigraphy of Chisulryoung Volcanic Formation (CVF).

\begin{tabular}{lll}
\hline Events & Member & Description \\
\hline Intrusion & & Gadaeri granite intrusion K/Ar biotite age: 63.9 \pm 1.8 Ma (Reedman et al., 1989) \\
\hline 2nd eruptive cycle & A4 & $\begin{array}{l}\text { Welded lithic-rich tuff } \\
\text { U/Pb zircon age: } 67.7 \pm 2.1 \text { Ma (Jeong et al., 2015) }\end{array}$ \\
\hline Intrusion & Cheokwari granodiorite intrusion K/Ar hornblende age: $76.3 \pm 11.7$ Ma (Reedman et al., 1989) \\
\hline 1st eruptive cycle & S3 & Tuffaceous sediments \\
& A3 & Welded lapilli tuff \\
& S2 & Tuffaceous sediments \\
& A2 & Welded lapilli tuff \\
S1 & Tuffaceous sediments \\
A1 & Welded lapilli tuff \\
Country rocks & So zircon age: $72.8 \pm 1.7$ Ma (Jeong et al., 2015) \\
\hline
\end{tabular}

AMS analysis explored in the present study will likely work well in other ignimbrite units of late Cretaceous age in the southeastern Korea.

\section{GEOLOGY}

The base of the CVF rests unconformably on top of lateCretaceous mudstones and sandstones of non-marine origin. Along the gorges of eastern side, ignimbrites occur in hornfels contact with the mudstone (Figure $2 \mathbf{A}$ ), evidence of contact metamorphism caused by hot ash-flow tuffs (Figure 2B). At the very basal contact, dyke-like flames of dark mudstones intrude the tuff layer (Figure 2C), resulting from fluidization of wet sediments at the hot tuff contact (Kokelaar, 1982).

The loosely welded massive pumice-rich tuff, with a maximum thickness of $120 \mathrm{~m}$, crops out at the lower part of A4 member (Figures 2D,E). The upper part of A4 member, as much as $100-120 \mathrm{~m}$ thick, is densely welded lithic-rich tuff (Figures 2F,G). The densely welded tuff commonly has abundant lithic fragments, but shards and pumice are exceedingly rare (Figure 2F). The densely welded tuff displays rheomorphic flow structures with highly flattened lenticular pumice fragments and concentration of pumice fiammes (Figure 2G).

The lower part of A4 member contains phenocrysts of resorbed plagioclase and lesser amount of quartz and biotite together with lithic fragments in a matrix of devitrified shards (Figures 3A,B). The pumice is in lapilli size, and it is more coarsely crystallized than the matrix shards (Figures 3A,B). The groundmass is aphanitic, consisting of cryptocrystalline and spherulitic feldspars and quartz (Figures 3A,B). In many cases, ignimbrites contain feldspars and anhedral quartz phenocrysts in a matrix with a small amount of devitrified glass shards and pumice fragments (Figures 3C,D).

The upper part of A4 member contains abundant rhyolite lapilli and rhyolite blocks within a mainly devitrified brown glassy and spherulitic groundmass of shards and pumice fragments (Figures 3E,F). About 30-50\% of rocks are occupied by broken pieces of mm-sized rhyolite fragments. Mineralogy of mm-sized rhyolite fragments includes resorbed plagioclase (50\%), K-feldspar (20\%), quartz (5\%), and other minor accessory components of biotite, magnetite, and apatite (Figures $3 \mathbf{E}, \mathbf{F}$ ). In particular, plagioclase feldspar is replaced by sericite and $\mathrm{K}$ feldspar along the fractures or crystal edges (Figures 3E,F). There is evidence that some cuspate shards appeared to have been squeezed between larger silicate minerals (Figures 3E,F). They are seen to be less than a few $\mathrm{mm}$ long and are generally replaced by axiolitic alkali feldspar. Phenocrysts are mainly of fragmented resorbed plagioclase and quartz, but also include biotite, sphene, and magnetite (Figures 3E,F). The most abundant phenocrysts are plagioclase, mostly irregular in shape with well-developed oscillatory or normal zoning (Figures 3E,F). The next abundant phenocrysts are K-feldspars and quartz, occurring as subhedral to euhedral crystals (Figures 3E,F). Quartz, K-feldspar, and plagioclase crystals are rarely more than a few millimeters long (Figures 3E,F).

Rheomorphic tuff showed well-developed eutaxitic textures and is composed predominantly of glass shards and pumice with minor amounts of lithic fragments and crystals in a reddish devitrified matrix (Figures 3G,H). For rheomorphic tuffs, orientation of rock fabrics runs parallel to the elongation of glass shards and to the flow banding within K-feldspar (Figures 3G,H).

\section{ROCK MAGNETIC PROPERTIES}

A detailed paleomagnetic analysis of the CVF was reported elsewhere (Jeong et al., 2015), hence, only a new rock magnetic investigation is described here. For sample 27A, the alternatingfield (AF) decays of natural remanent magnetization (NRM) were relatively hard, with median destructive field (MDF) of $\sim 30 \mathrm{mT}$ (Figure 4A). Thermal demagnetization on the sister sample $27 \mathrm{~T}$ showed a narrow unblocking temperature spectrum 

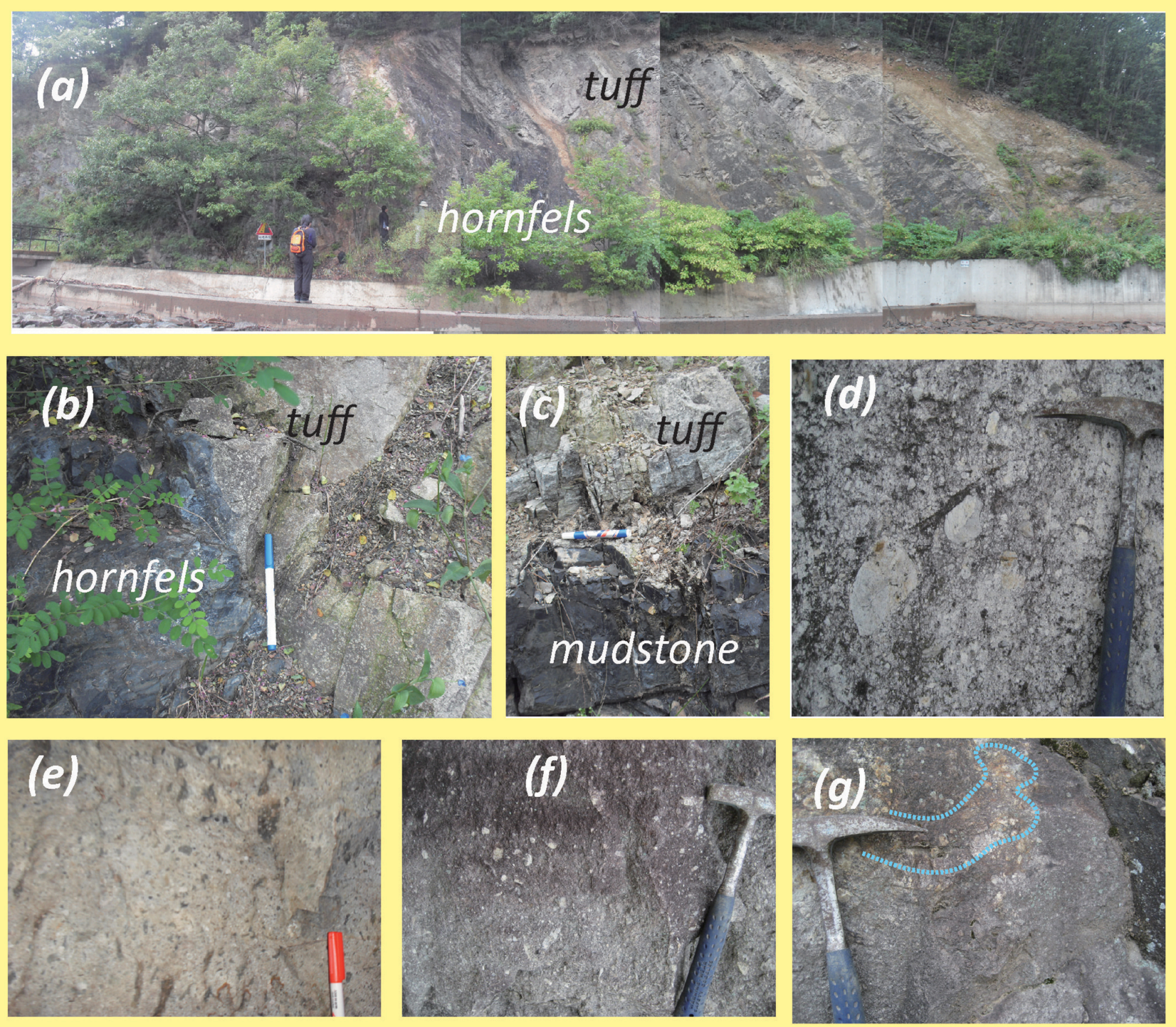

FIGURE 2 | (A) Contact metamorphism produced hornfels along the mudstone-ignimbrite boundaries. (B) Hornfelsic mudstone-ignimbrite boundary in a magnified scale. (C) Dyke-like flames of dark mudstones intrude the tuff layer. (D) Devitrified shards developed in a loosely welded tuff. (E) Pumice-rich tuff contains phenocrysts of resorbed plagioclase. (F) Densely welded lithic-rich tuff. (G) Rheomorphic structure with highly flattened lenticular pumice fragments and concentration of pumice fiammes (highlighted with dashed lines).

of $500-600^{\circ} \mathrm{C}$ (Figure $4 \mathrm{~B}$ ). An initial plateau with relatively high MDF in AF demagnetization and a sharp drop of NRM near $580^{\circ} \mathrm{C}$ in thermal demagnetization are characteristics of fine-grained magnetite (Figure 4). Existence of the distributed coercivity (sample 22A in Figure $\mathbf{4 A}$ ) and the distributed unblocking temperature spectra (sample $22 \mathrm{~T}$ in Figure 4B) suggests a presence of coarse-grained magnetite. Most examples fall between these extremes (sample 26A, 26T, 29A, 29T), indicating that fine- to coarse-grained magnetite is the main remanence carrier (Figure 4).

Acquisition of isothermal remanent magnetization (IRM), back-field demagnetization of IRM, and strong-field magnetic hysteresis were measured to confirm rock magnetic properties inferred from demagnetization experiments. IRM was acquired by magnetizing a sample in a strong, uniform, DC magnetic field from 30 to $1000 \mathrm{mT}$ produced by an impulse magnetizer (model ASC IM-10). A stepwise back-field was applied for the samples on which IRM was imparted to determine remanent coercivity. Room temperature magnetic hysteresis measurements in a maximum field of $1.0 \mathrm{~T}$ were performed on an alternating gradient force magnetometer. Hysteresis loops were obtained from 109 chips. Hysteresis parameters of saturation magnetization $\left(\mathrm{M}_{\mathrm{s}}\right)$, saturation remanence $\left(\mathrm{M}_{\mathrm{rs}}\right)$, and coercive force $\left(B_{c}\right)$ were determined after appropriate paramagnetic 

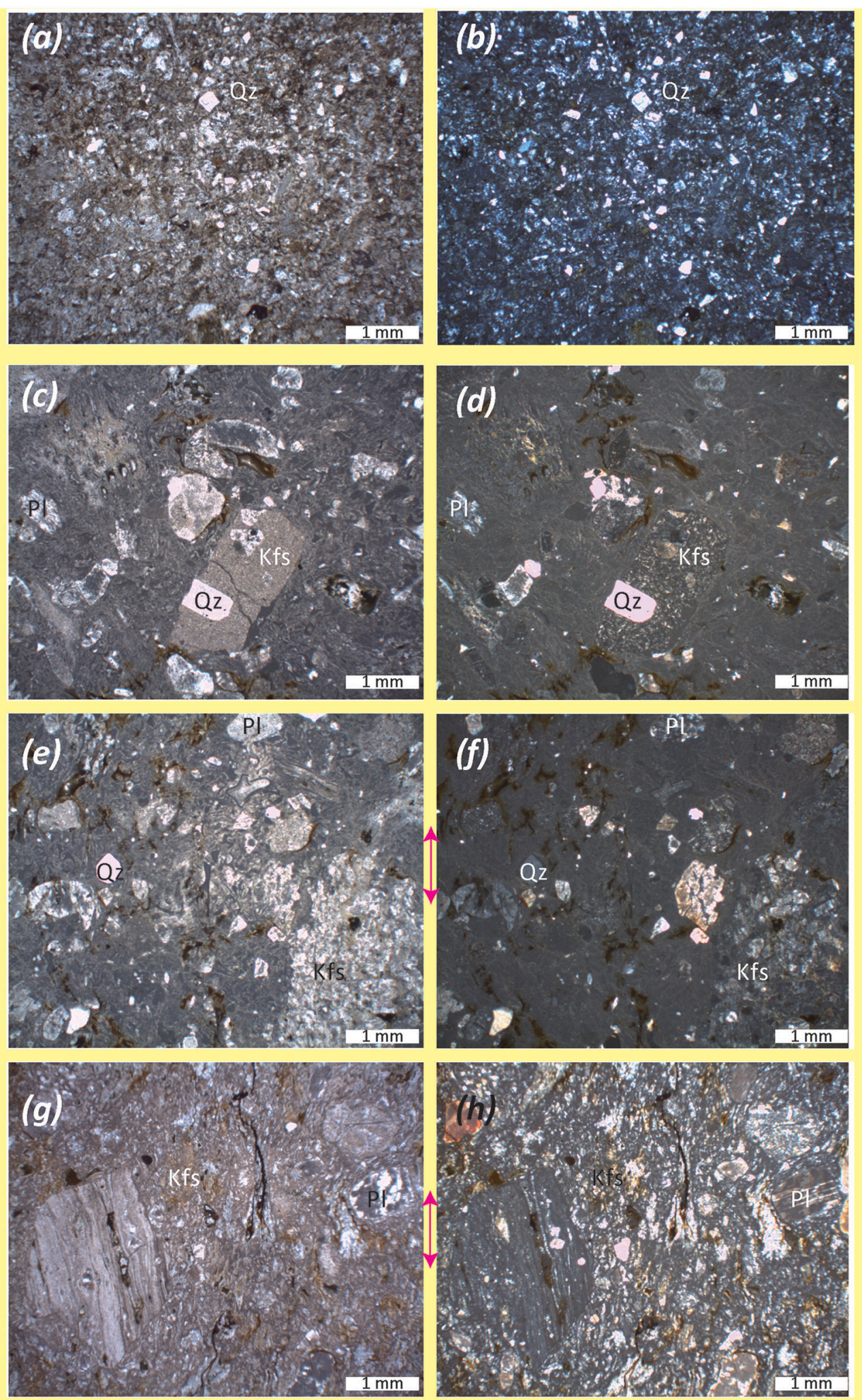

FIGURE 3 | Thin section images and microstructures of CVF. Kfs, K-feldspars; PI, plagioclase feldspar; Qz, quartz; plain polarized light (left panel) and crossed polarizers (right panels). (A,B) Loosely welded tuff with lithic fragments in a matrix of devitrified shards. (C,D) Loosely welded pumice-rich tuff with feldspars and 


\section{FIGURE 3 | Continued}

anhedral quartz phenocrysts in a matrix of pumice fragments. (E,F) Welded rhyolitic tuff comprise from 30 to $50 \%$ of the broken pieces of mm-sized rhyolite fragments and resorbed plagioclase (50\%), K-feldspar (20\%), and quartz (5\%). (G,H) Rheomorphic tuff showed well-developed eutaxitic textures. For welded-tuffs, orientation of welding plane is represented as double-sided arrows.
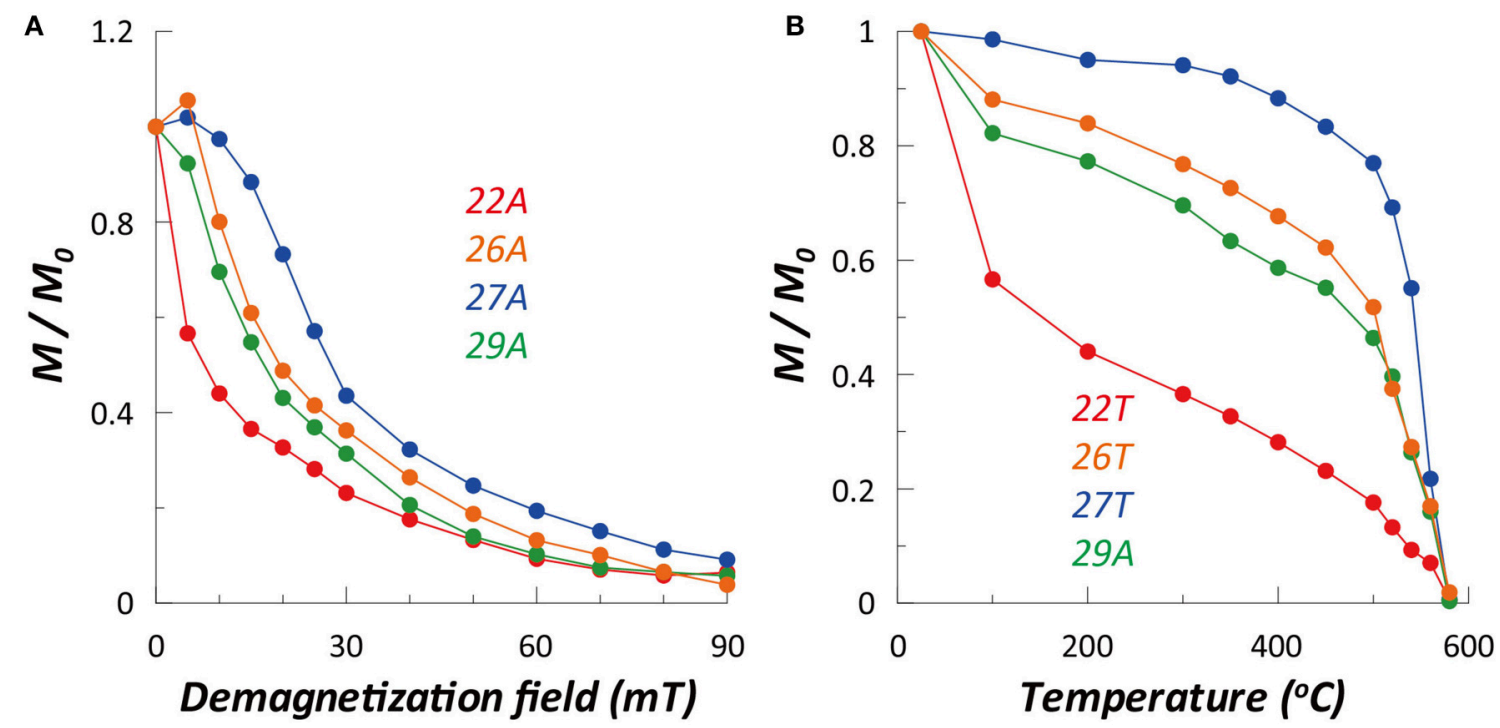

FIGURE 4 | Examples of (A) AF and (B) thermal demagnetization results.

correction. Values of remanence coercivity $\left(\mathrm{B}_{\mathrm{cr}}\right)$ were obtained from back-field measurements.

The results can be classified into three categories. Most results (61 out of 109 chips) were Type A, characterized by a gradual increase of magnetization up to $300 \mathrm{mT}$ in IRM acquisition with $\sim 100 \mathrm{mT}$ of remanent coercivity $(22 \mathrm{~K}, 29 \mathrm{~K}$ in Figure 5A). The ratio of $M_{r s} / M_{s}$ and $B_{c r} / B_{c}$ for the 61 chips (Figure 5B) lie in the pseudo-single-domain (PSD) range according to the conventional criteria (Day et al., 1977) or PSD trend curves (Dunlop, 2002). Type B results (42 out of 109 chips) showed a rapid increase of magnetization during acquisition of IRM and a quick decay of IRM during backfield demagnetization (26K, $27 \mathrm{~K}$ in Figure 5A). In a Day plot, Type $\mathrm{B}$ results showed slight bias toward superparamagnetic contribution (Figure 5B). Type C data (6 out of 109 chips) showed a continuous increase of magnetization with increasing field (27L, 27M in Figure 5A). For Type C, the saturation is not achieved up to a maximum field of $1 \mathrm{~T}$, and the remanence coercivity was $>300 \mathrm{mT}(27 \mathrm{~L}, 27 \mathrm{M}$ in Figure 5A). Type $\mathrm{C}$ data showed values of $\mathrm{M}_{\mathrm{rs}} / \mathrm{M}_{\mathrm{s}} \approx 0.4$ and $\mathrm{B}_{\mathrm{cr}} / \mathrm{B}_{\mathrm{c}} \approx 2.5$ (Figure 5B). It is very likely that Type $C$ bears more than two components of magnetic minerals, with a wide range of grain size distribution for each magnetic mineral. Presence of dual components may compromise the fidelity of magnetic fabric analysis. Hence, Type C samples were excluded in further AMS analysis. It is fortunate that Type $\mathrm{C}$ results were found only from six chips from three paleomagnetic samples collected to the eastern side of site 27 .

\section{AMS ANALYSIS}

Applying the AMS analysis on the first eruptive cycle was impossible as the rocks are not fully exposed and caldera boundaries are mostly uncertain or lacking. Hence, in the present study, we focused only on the AMS studies on the second eruptive cycle (A4 and the IWT), which are the last product of pyroclastic activity with well-confined basin-like caldera structure (Figures 1, 6). A total of 263 oriented samples were collected at nineteen sites from the A4 member (Figure 1). We also collected 45 oriented samples at five sites from the IWT (Figure 6). It is undoubtedly true that magnetic interpretation of pyroclastics is dependent on the structural correction to restore the paleo-horizons. It would be fair to mention that no structural correction was employed in the present study as the degree of bedding tilts was unavailable.

AMS was determined by measuring magnetic susceptibility $(k)$ induced along different directions for each sample. We used a computerized magnetic susceptibility meter on a Kappabridge KLY-2, following a rotatable scheme with 15 measuring positions (Jelinek, 1976). The results were then analyzed using a commonly used software "PmagPy" (Tauxe, 2010), where confidence ellipses were calculated on the basis of the Jelinek method (inner ellipses) and the site parametric bootstrap statistics (outer ellipses) (Figures 1, 6). Eigenvalue of normalized mean magnetic susceptibility and directions of the associated eigenvectors for $k_{1}, k_{2}$, and $k_{3}$ are provided (Tables 2, 3). Eigenvectors were displayed on an equal area plot using the lower hemisphere 

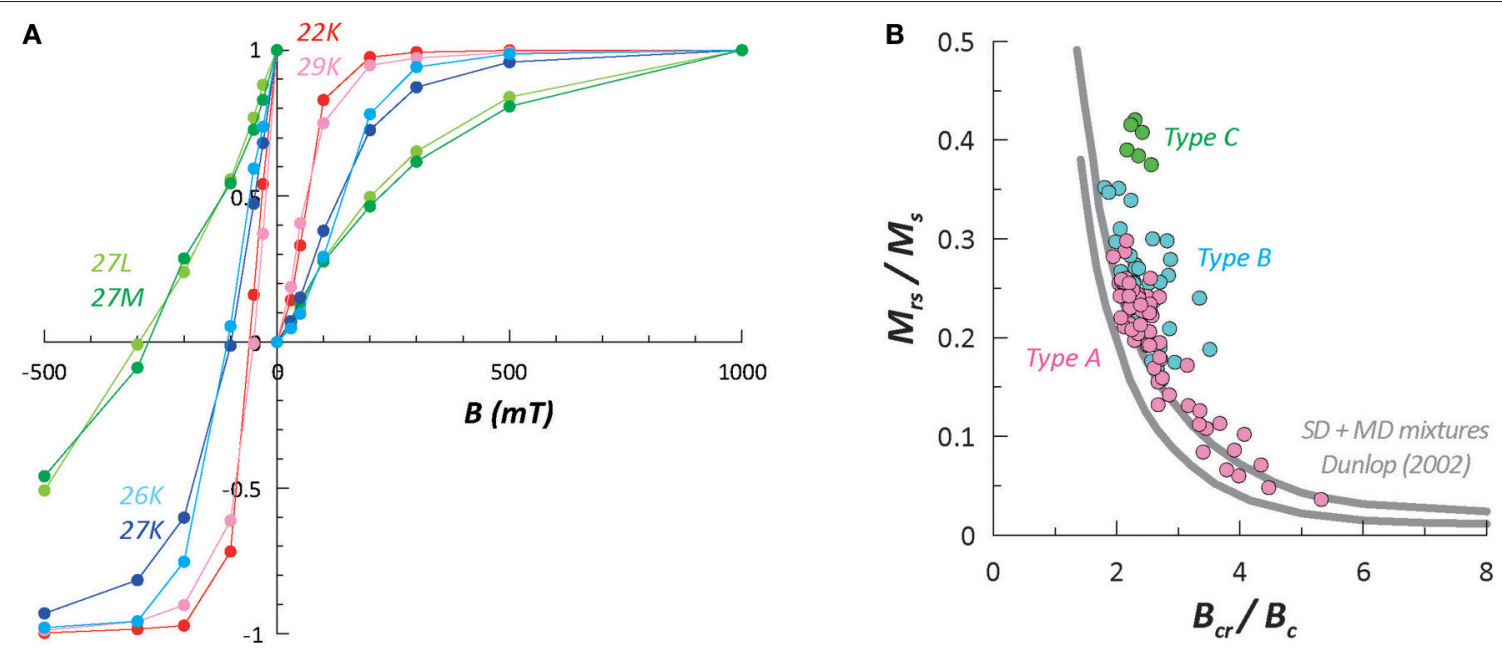

FIGURE 5 | (A) Examples of normalized isothermal remanent magnetization (IRM) acquisition and the back-field demagnetization curves. For 22 and $29 \mathrm{~K}$, a gradual increase of magnetization up to $300 \mathrm{mT}$ in IRM acquisition with $\sim 100 \mathrm{mT}$ of remanent coercivity was observed. A rapid increase of magnetization during acquisition of IRM and a quick decay of IRM during back-field demagnetization was observed for 26 and $27 \mathrm{~K}$. For $27 \mathrm{~L}$ and $27 \mathrm{M}$, the saturation was not achieved up to a maximum field of $1 \mathrm{~T}$, and the remanence coercivity was $>300 \mathrm{mT}$. (B) Hysteresis data in a Day plot (Day et al., 1977) with the single-domain and multidomain mixing trend curves (Dunlop, 2002).

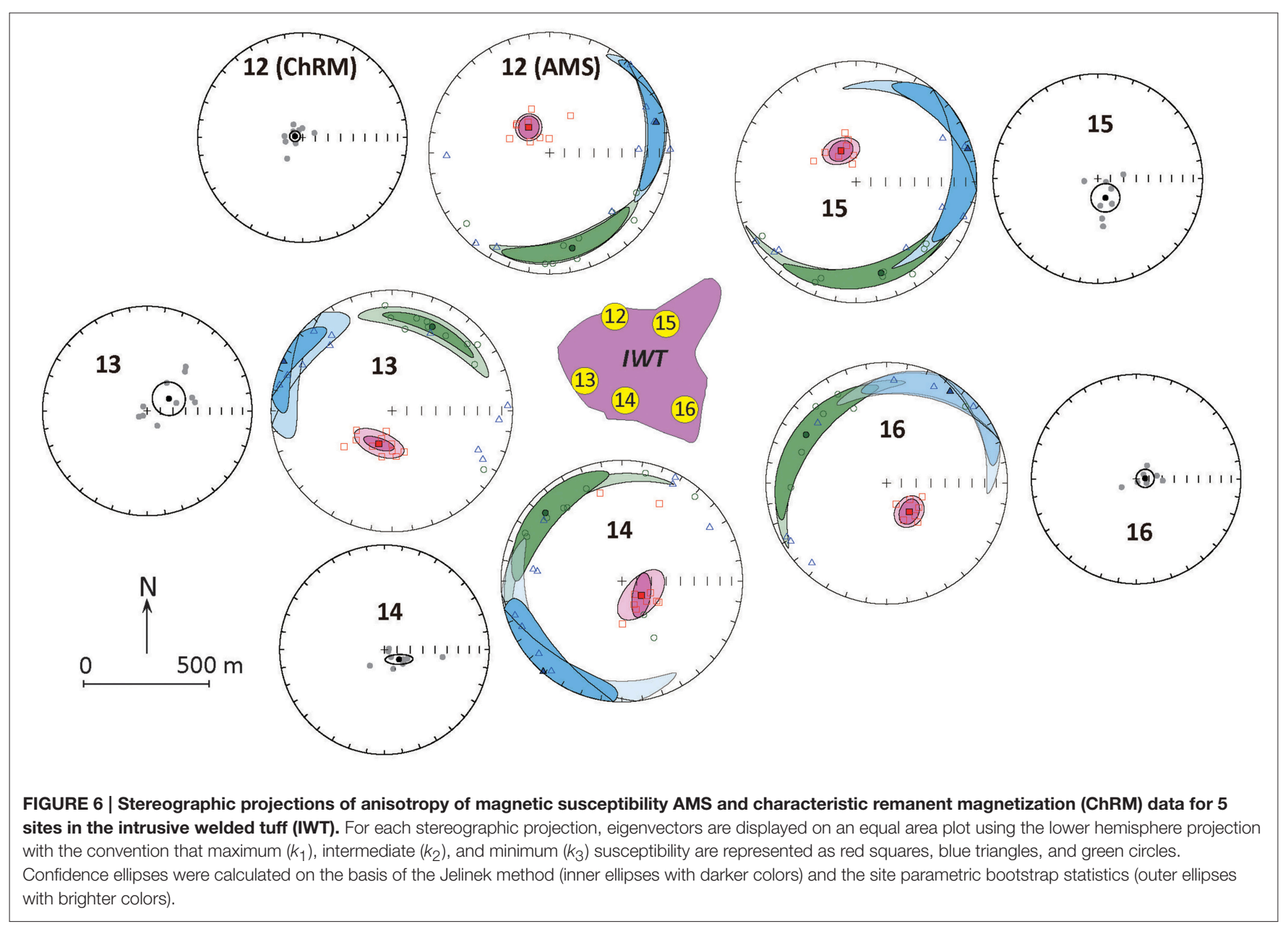


TABLE 2 | Site-mean AMS statistics of A4 member.

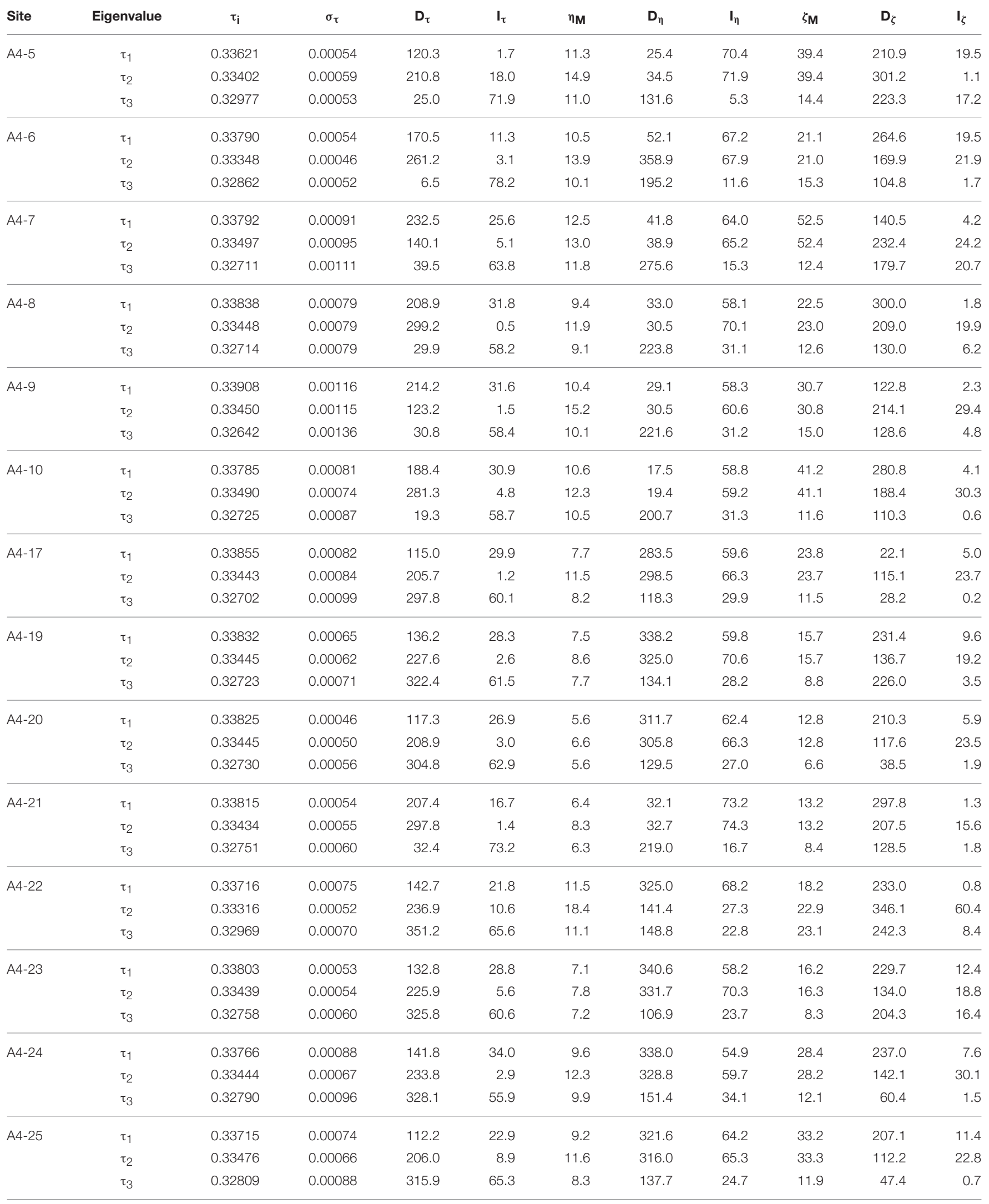


TABLE 2 | Continued

\begin{tabular}{|c|c|c|c|c|c|c|c|c|c|c|c|}
\hline Site & Eigenvalue & $\tau_{\mathbf{i}}$ & $\sigma_{\tau}$ & $\mathbf{D}_{\tau}$ & $\mathbf{I}_{\tau}$ & $\eta_{M}$ & $\mathbf{D}_{\eta}$ & $I_{\eta}$ & $\zeta_{M}$ & $\mathbf{D}_{\zeta}$ & $\mathbf{I}_{\zeta}$ \\
\hline \multirow[t]{2}{*}{ A4-26 } & $\tau_{1}$ & 0.33537 & 0.00041 & 139.2 & 0.8 & 12.2 & 241.5 & 86.3 & 32.9 & 49.2 & 3.7 \\
\hline & $\tau_{2}$ & 0.33383 & 0.00040 & 49.1 & 13.3 & 14.6 & 239.3 & 76.5 & 32.3 & 139.6 & 2.3 \\
\hline \multirow[t]{2}{*}{ A4-27 } & $\tau_{1}$ & 0.33772 & 0.00071 & 146.0 & 31.1 & 8.2 & 344.9 & 57.5 & 16.8 & 241.2 & 8.6 \\
\hline & $\tau_{2}$ & 0.33395 & 0.00056 & 239.0 & 5.0 & 12.4 & 342.2 & 69.3 & 17.0 & 147.2 & 20.0 \\
\hline \multirow[t]{3}{*}{ A4-28 } & $\tau_{1}$ & 0.33779 & 0.00083 & 207.2 & 21.6 & 9.6 & 57.3 & 65.4 & 18.7 & 301.7 & 11.2 \\
\hline & $\tau_{2}$ & 0.33340 & 0.00075 & 301.1 & 9.9 & 18.6 & 210.3 & 4.8 & 22.0 & 94.9 & 79.0 \\
\hline & $\tau_{3}$ & 0.32882 & 0.00096 & 54.2 & 66.1 & 9.5 & 210.3 & 22.1 & 21.7 & 303.9 & 8.8 \\
\hline A4-29 & $\tau_{1}$ & 0.33847 & 0.00079 & 210.1 & 23.9 & 8.9 & 27.9 & 66.1 & 19.8 & 119.7 & 0.8 \\
\hline \multirow{2}{*}{ A4-30 } & $\tau_{2}$ & 0.33376 & 0.00078 & 292.7 & 6.1 & 14.9 & 36.3 & 65.6 & 18.4 & 200.0 & 23.5 \\
\hline & $\tau_{3}$ & 0.32823 & 0.00102 & 30.4 & 51.4 & 8.5 & 198.3 & 38.0 & 15.0 & 292.9 & 5.9 \\
\hline
\end{tabular}

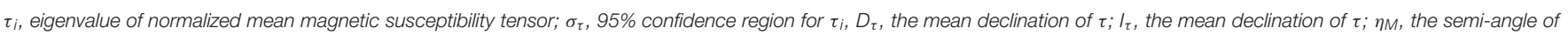

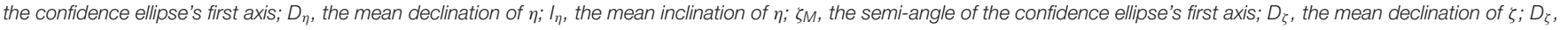
the mean inclination of $\zeta$.

TABLE 3 | Site-mean AMS statistics of the intrusive welded tuff (IWT).

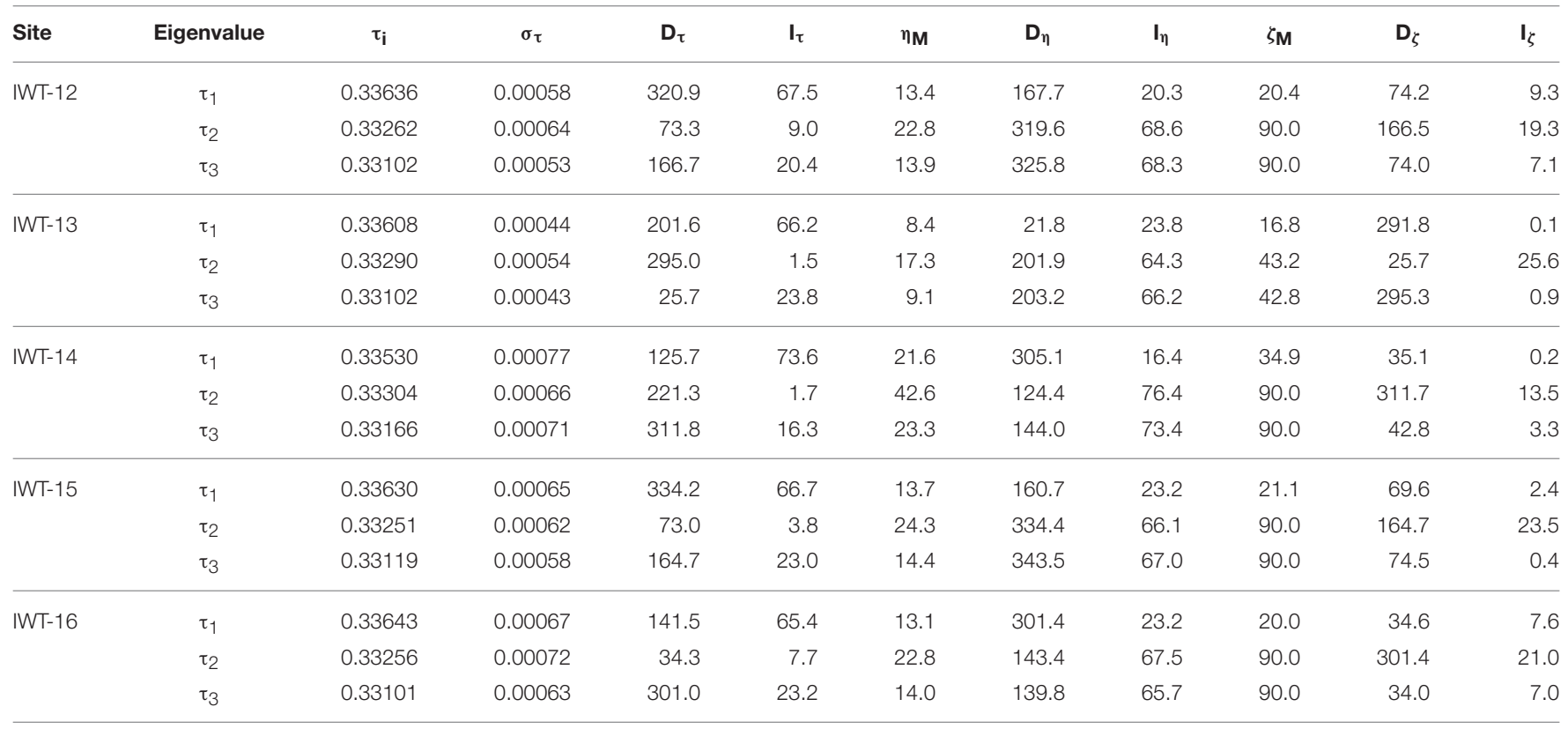

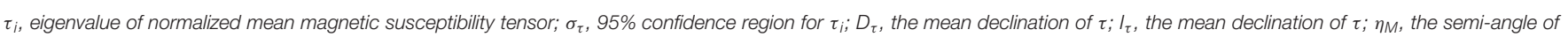
the confidence ellipse's first axis; $D_{\eta}$, the mean declination of $\eta ; I_{\eta}$, the mean inclination of $\eta$; $\zeta_{M}$, the semi-angle of the confidence ellipse's first axis; $D_{\zeta}$, the mean declination of $\zeta$; $D_{\zeta}$, the mean inclination of $\zeta$.

projection with the convention that maximum $\left(k_{1}\right)$, intermediate $\left(k_{2}\right)$, and minimum $\left(k_{3}\right)$ susceptibility are represented as squares, triangles, and circles (Figures 1, 6). For A4 member, the result was compatible with the oblate fabrics with a tight clustering of $k_{3}$ near the vertical and a distributed $k_{1}$ and $k_{2}$ directions at shallower foliation planes (Figure 1). Contrary to A4 member, the IWT showed a distinctive prolate fabric with high inclination of $k_{1}$ (Figure 6). 

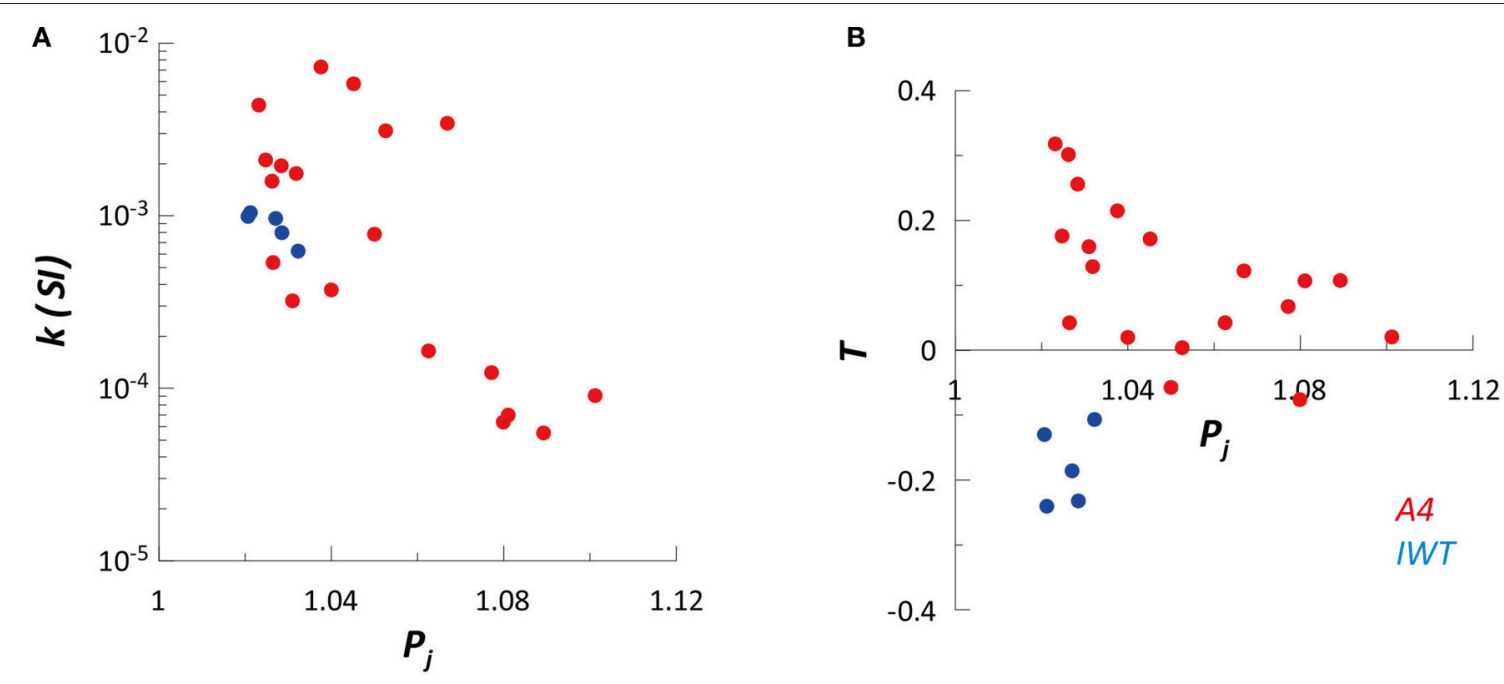

FIGURE 7 | (A) Mean values of magnetic susceptibility are inversely proportional to the degree of anisotropy $\left(P_{j}\right)$. (B) Magnetic fabric was analyzed by comparing $P_{j}$ in relation to the shape parameter $(T)$. While the A4 member showed a prevalent oblate fabric, the IWT showed a dominance of prolate fabric.

TABLE 4 | Site-mean AMS parameters of A4 member.

\begin{tabular}{|c|c|c|c|}
\hline Site & $k_{\text {mean }}\left(10^{-3} \mathrm{SI}\right)$ & $P_{j}$ & $T$ \\
\hline 5 & 7.28 & 1.038 & 0.22 \\
\hline 6 & 2.11 & 1.025 & 0.18 \\
\hline 7 & 0.37 & 1.040 & 0.02 \\
\hline 8 & 1.59 & 1.026 & 0.30 \\
\hline 9 & 1.95 & 1.028 & 0.26 \\
\hline 10 & 5.82 & 1.045 & 0.17 \\
\hline 17 & 0.09 & 1.101 & 0.02 \\
\hline 19 & 0.06 & 1.080 & -0.08 \\
\hline 20 & 0.12 & 1.077 & 0.07 \\
\hline 21 & 0.78 & 1.050 & -0.06 \\
\hline 22 & 0.32 & 1.031 & 0.16 \\
\hline 23 & 0.06 & 1.089 & 0.11 \\
\hline 24 & 0.07 & 1.081 & 0.11 \\
\hline 25 & 3.11 & 1.053 & 0.00 \\
\hline 26 & 4.38 & 1.023 & 0.32 \\
\hline 27 & 3.44 & 1.067 & 0.12 \\
\hline 28 & 1.76 & 1.032 & 0.13 \\
\hline 29 & 0.54 & 1.027 & 0.04 \\
\hline 30 & 0.16 & 1.063 & 0.04 \\
\hline
\end{tabular}

kmean, mean susceptibility; T, shape parameter (Jelinek, 1981); $P_{j}$, degree of anisotropy (Jelinek, 1981).

Mean magnetic susceptibilities were clustered in the range from $5.5 \times 10^{-5}$ SI to $7.3 \times 10^{-3}$ SI (Figure 7A). The degree of anisotropy $P_{j}$ (Jelinek, 1981) was $<1.101$ (Tables 4, 5). Specimen level data were tabulated with eigenvalues and directions of the associated eigenvectors for $k_{1}, k_{2}$, and $k_{3}$ (Supplementary data repository, Data-1.xls in Excel format). In particular, the IWT showed a very low degree of anisotropy $\left(P_{j}<1.05\right)$ (Figure 7A). There is a general correlation that the degree of anisotropy was inversely proportional to the mean values of
TABLE 5 | Site-mean AMS parameters of the (IWT).

\begin{tabular}{cccc}
\hline Site & $\boldsymbol{k}_{\text {mean }}\left(\mathbf{1 0}^{-\mathbf{3}} \mathbf{S I}\right)$ & $\boldsymbol{P}_{\boldsymbol{j}}$ & $\boldsymbol{T}$ \\
\hline 12 & 0.62 & 1.032 & -0.11 \\
13 & 0.97 & 1.027 & -0.19 \\
14 & 1.04 & 1.021 & -0.24 \\
15 & 0.80 & 1.029 & -0.23 \\
16 & 1.00 & 1.021 & -0.13 \\
\hline
\end{tabular}

$k_{\text {mean, }}$ mean susceptibility; $T$, shape parameter (Jelinek, 1981); $P_{j}$, degree of anisotropy (Jelinek, 1981).

magnetic susceptibility (Figure 7A). In fact, results with high bulk susceptibility have low degree of anisotropy while those with low bulk susceptibility have high degree of anisotropy (Figure 7A).

When magnetic fabric was analyzed in terms of $P_{j}$ vs. shape parameter (T) (Jelinek, 1981), results for A4 member are biased toward positive shape parameters (with two exceptionally low values of $T>-0.08$ ), suggesting a prevalent oblate fabric due to welding process (Figure 7B). A notably distinct negative trend with $T<-0.11$ was observed for the IWT (Figure 7B), indicating a predominant prolate fabric.

\section{SOURCE IMPLICATION}

The successful application of AMS method relies on the fact that the $k_{1}$ aligns parallel to the flow azimuth of ignimbrites. This consensus is true in the case of a normal fabric where the elongation of PSD or MD grains of magnetite commonly parallels the flow azimuth. On the other hand, it has been shown that SD magnetite exhibits an "inverse" fabric where the $k_{3}$ aligned along the elongated axes of the samples (Potter and Stephenson, 1988; Rochette, 1988; Ort et al., 1999). Thus, it is necessary to avoid the presence of an inverse fabric that can compromise the past flow 

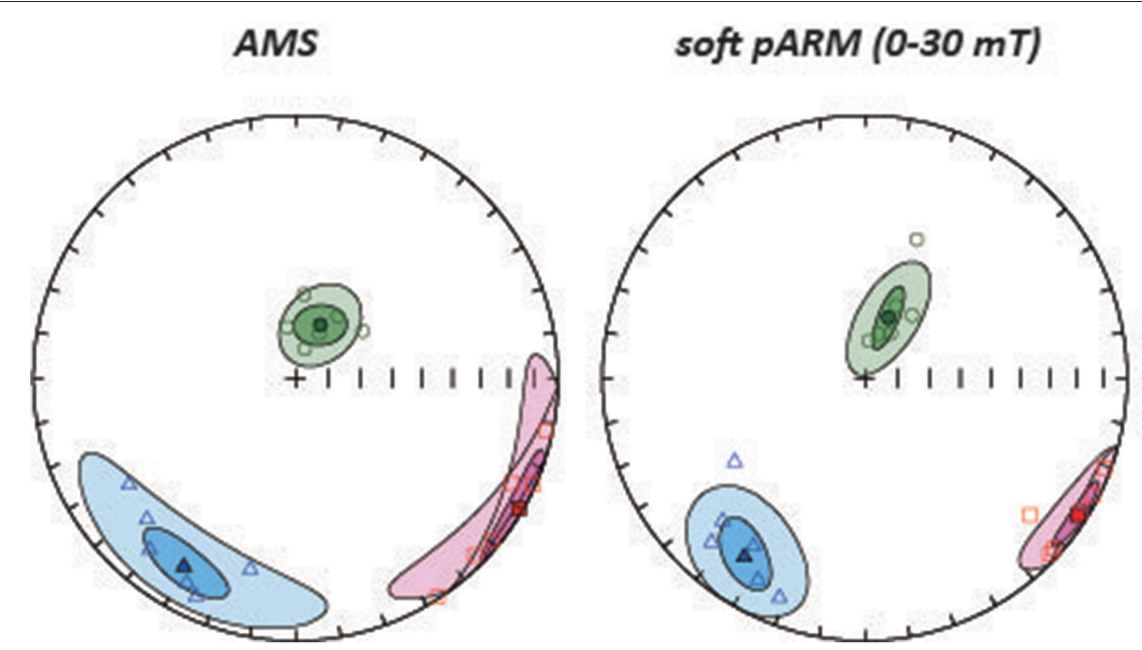

\section{hard pARM (30-100 mT)}

FIGURE 8 | Stereographic projections of anisotropy of magnetic susceptibility (AMS), anisotropy of partial anhysteretic remanent magnetization (partial AARM). Soft partial AARM (0-30 mT) and hard partial AARM (30-100 mT) were produced in a bias DC field of $100 \mu \mathrm{T}$. Samples were AF demagnetized to $100 \mathrm{mT}$ before each partial ARM acquisition experiment. For each stereographic projection, eigenvectors are displayed on an equal area plot using the lower hemisphere projection with the convention that maximum $\left(k_{1}\right)$, intermediate $\left(k_{2}\right)$, and minimum $\left(k_{3}\right)$ susceptibility are represented as red squares, blue triangles, and green circles. Confidence ellipses were calculated on the basis of the Jelinek method (inner ellipses with darker colors) and the site parametric bootstrap statistics (outer ellipses with brighter colors).

direction. Several lines of experimental observations indicate that PSD and MD magnetites are the main remanence carriers. First, both AF and thermal demagnetization spectra showed typical characteristics of PSD and MD magnetite (Figure 4). Second, acquisition of IRM and back-field demagnetization IRM also demonstrated the presence of PSD and MD magnetites (Figure 5A). Third, values of remanence ratio from the magnetic hysteresis measurements were $0.2-0.3$, suggesting fine-grained non-SD magnetite as remanence carriers (Figure 5B). Thus, we can safely exclude the presence of an inverse fabric for A4 member and the IWT.

In terms of lithologic ground, ignimbrites are dominated by felsic minerals such as quartz, k-feldspar and plagioclase. There is a possibility that these silicates host magnetite inclusions along the cleavage planes. Then it is natural to consider that magnetite inclusions within silicates would be finer than those in the matrix. If so, AMS would be controlled by relatively coarser grains of magnetite while remanent magnetization would be dominated by relatively finer grains. The best candidate for such a bimodal behavior would be the type B samples (Figure 5). To check a possible composite nature of the AMS fabric, difference between AMS and anisotropy of partial anhysteretic remanent magnetization (partial AARM) was compared. In general, AMS fabrics and partial AARM tensors are similar unless there is a composite fabric (Aubourg et al., 1995, 2000; Werner and Borradaile, 1996; Robion et al., 1999; Rochette et al., 1999; Trindade et al., 1999). In practice, a composite fabric may cause distinctively different directional patterns among AMS, soft partial AARM, and hard partial AARM (Aubourg and Robion, 2002). In a spirit of Aubourg and Robion (2002), soft partial AARM (0-30 mT) and hard partial AARM (30-100 mT) were produced in a bias DC field of $100 \mu \mathrm{T}$. Samples were AF demagnetized to $100 \mathrm{mT}$ before each partial ARM acquisition experiment. We set AC boundary at $30 \mathrm{mT}$ because $\mathrm{AF}$ demagnetization of NRM typically yielded median destructive field of $\approx 30 \mathrm{mT}$. Directions of AMS, soft partial AARM, and hard partial AARM are consistent with one another, indicating that azimuthal direction inferred from AMS is not compromised by the composite fabric (Figure 8). Decreasing degree of anisotropy with increasing magnetite content (Figure 7A) may reflect an isotropic rather than preferential accretion of finer grains, and the resulting partial AARM tensor became more triaxial than the oblate AMS fabric (Figure 8).

For A4 member, the magnetic foliations were prevailing while magnetic lineation was weakly developed (Figure 1). Occurrence of prominent oblate fabrics in A4 member (Figure 1) indicates imbrications of pyroclastic material imposed by compaction and welding (Grunder et al., 2004). It is conjectured here that magnetite was probably oriented by laminar pyroclastic density flows in the later stages of pyroclastic transport.

There are two similar but fundamentally different opinions in determining the flow patterns of ignimbrites. The first opinion describes that magnetic minerals align themselves parallel to the flow azimuth and the magnetic foliation reflects the imbrication process. In principle, the AMS ellipsoid of $k_{1}$ and $k_{2}$ forms the plane of welding in ignimbrites, on which $k_{1}$ lies parallel to the flow azimuth (e.g., Wolff et al., 1989; Rochette et al., 1992, 1999; Palmer and MacDonald, 2002; Bolle et al., 2010; Ort et al., 2013). If so, ignimbrites may reveal $k_{3}$ pole distribution of magnetic foliation and have distinctive bilobed dispersal patterns traverse to flow direction (e.g., MacDonald and Palmer, 1990; Palmer et al., 1991; Palmer and MacDonald, 1999, 2002). The second opinion adopts analogy to the imbrication of stream 


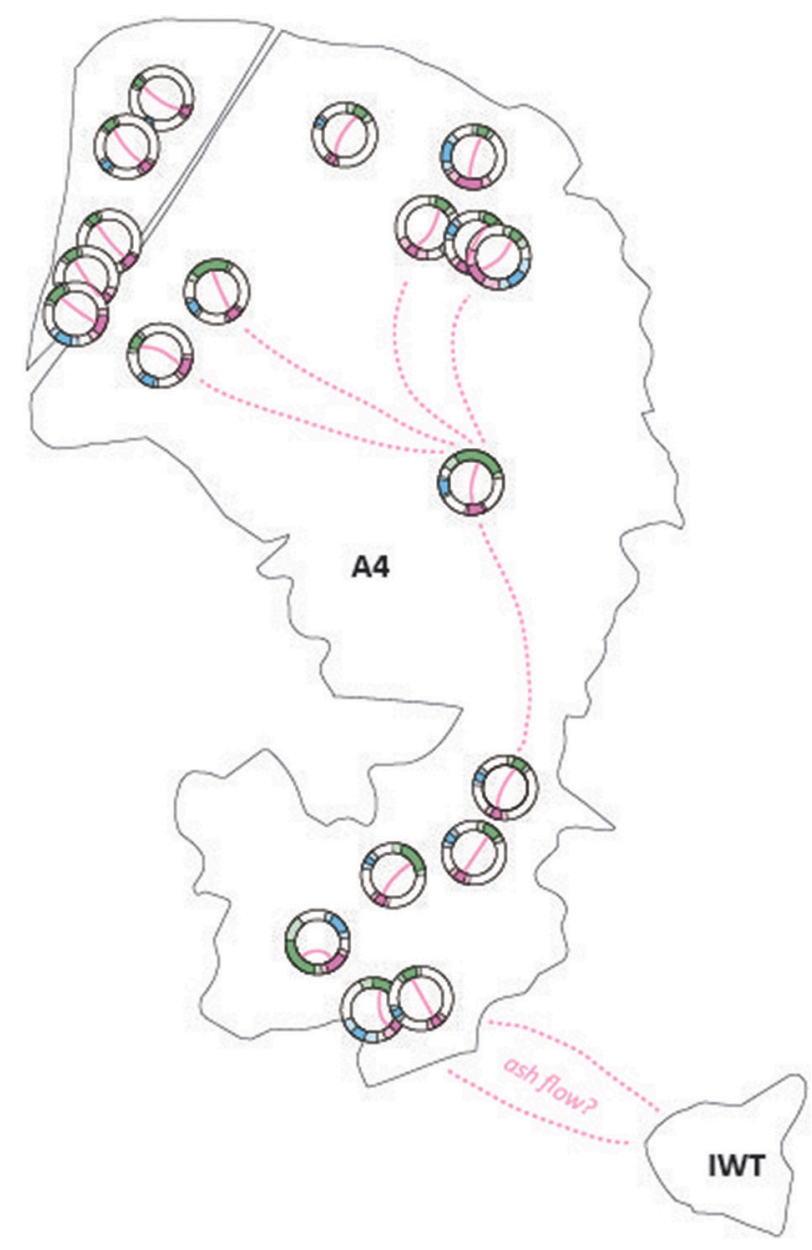

FIGURE 9 | For each site, flow azimuth of ignimbrites was graphically expressed by connecting lines between $\boldsymbol{k}_{\mathbf{1}}$ and $\boldsymbol{k}_{\mathbf{3}}$ directions in ring plots. Directional confidence of $k_{1}, k_{2}$, and $k_{3}$ was displayed for the Jelinek method (darker colors) and the site parametric bootstrap analysis (brighter colors). Assuming a single source area, the geometrically most probable source would be close to the vicinity of the IWT. clasts, as the plane of magnetic foliation ( $k_{1}$ and $\left.k_{2}\right)$ tilts downward and upstream (Hillhouse and Wells, 1991; Petronis and Geissman, 2009). Then, the flow direction is indicated by the azimuthal orientation of the downward end of $k_{1}$ on stereographic projections.

The preceding discussion on either opinion indicates that the flow azimuth of ignimbrites can be determined by connecting mean directions of $k_{1}$ or $k_{3}$ between neighboring sites. In the present study, pyroclastic flow directions of ignimbrites inferred by simply tracing back the directions of $k_{1}$ or $k_{3}$ are practically identical (Figure 9). Such intriguing directional similarity in tracing $k_{1}$ or $k_{3}$ is valid under the imposed limits of directional confidence of $k_{1}, k_{2}$, and $k_{3}$ for the Jelinek method (darker colors) and the site parametric bootstrap analysis (brighter colors) (Figure 9). Hence, for each site, flow azimuth of ignimbrites was graphically expressed by connecting lines from $k_{1}$ to $k_{3}$ directions in ring plots (Figure 9). Estimated flow azimuth of individual sites was diverging at the northern and southern ends, but was converging at the central bottleneck area (Figure 9). Sites in western margin showed southeastern flow azimuth while those in eastern margin revealed southwestern flow azimuth (Figure 9). It is puzzling that vectorial flow direction from $k_{1}$ to $k_{3}$ is prevailingly upward, difficult to imagine unless pyroclastic surges produce inverted welding structure. Although we cannot completely rule out the possibility, a local tectonic displacement or a regional tilting may alter the geometry of welding foliation.

Assuming a single source area, the geometrically most probable source would be close to the vicinity of the IWT (Figure 9). Our interpretation is in accordance with the earlier inference that the IWT would be the source of the CVF (Reedman et al., 1987). It can therefore be concluded that the IWT is the source of A4 member (Figure 9). It also matches well with the geochemical data where the ratio of $\mathrm{Zr} / \mathrm{TiO}_{2}$ and $\mathrm{Nb} / \mathrm{Y}$ showed tight clustering for $\mathrm{A} 4$ member and the IWT (Park, 1990). However, it remains to be shown whether comparable studies on detrital zircon might come to the same conclusion.

A final point of discussion involves unique magnetic features observed in the IWT. As a secondary coherent viscous mass flow after the emplacement (Wolff and Wright, 1991), rheomorphism generally produces a prolate fabric (Ellwood, 1982). The IWT showed eutaxitic textures nearly parallel to its subvertical contacts (Park, 1990). For the IWT, AMS data indicated poor to moderate minimum and intermediate axial clusters but good to excellent maximum axial clusters, which are consistent with the dominant prolate fabric patterns with respect to a near-vertical vent wall (Wolff et al., 1989). In addition, the IWT exhibited an anomalously high angle of magnetic lineation (Figure 6). It is worthy of note that characteristic remanent magnetization of IWT also yielded an anomalously high magnetic inclination (Figure 6). Therefore, it is plausible that the rheomorphism is responsible for the high magnetic inclination and prolate AMS fabric of the IWT as the welded tuff is squeezed along the rough-surfaced dyke walls due to agglutination.

\section{CONCLUSIONS}

1. The anisotropy of magnetic susceptibility (AMS) of late Cretaceous ash-flow tuffs in (CVF) showed a dominant oblate fabric with a tight clustering of $k_{3}$ (minimum axis of magnetic susceptibility) and shallow dispersal of $k_{1}$ (maximum axis of magnetic susceptibility) and $k_{2}$ (intermediate axis of magnetic susceptibility). Presence of predominant oblate fabrics in ignimbrites indicates clast imbrications imposed by compaction and welding.

2. Flow azimuth of ignimbrites inferred by tracing back the direction of $k_{1}$ or $k_{3}$ of each site is similar. Therefore, flow directions of ignimbrites were estimated from $k_{1}$ to $k_{3}$ directions in ring plots, strongly suggesting that the IWT is a potential source of caldera for ignimbrites. Such an inference is supported by geologic investigations, in which the IWT 
displays eutaxitic textures nearly parallel to its subvertical contacts.

3. A unique prolate fabric with an anomalously high magnetic inclination was observed for the IWT, resulting from rheomorphic flows as the welded tuff is squeezed along the rough-surfaced dyke walls due to agglutination.

\section{AUTHOR CONTRIBUTIONS}

$\mathrm{HH}$ and YY equally contributed to the draft of the work, data acquisition, and interpretation of data for the work. YY, SD, DS, and JK designed the work, revised the draft for intellectual merit, and maintained the integrity of investigation.

\section{REFERENCES}

Aubourg, C., Hebert, R., Jolivet, L., and Cartayrade, G. (2000). The magnetic fabric of metasediments in a detachment zone: the example of Tinos Island. Tectonophysics 321, 219-236. doi: 10.1016/S0040-1951(00)00049-4

Aubourg, C., and Robion, P. (2002). Composite ferromagnetic fabrics (magnetite, greigite) measured by AMS and partial AARM in weakly strained sandstones from western Makran, Iran. Geophys. J. Int. 151, 729-737. doi: 10.1046/j.1365246X.2002.01800.x

Aubourg, C., Rochette, P., and Bergmuller, F. (1995). Composite magnetic fabric in weakly deformed black shales. Phys. Earth Planet. Inter. 87, 267-278. doi: 10.1016/0031-9201(94)02962-B

Beck, M. E., Sheriff, S. D., Diehl, J. F., Hailwood, E. A., and Lipman, P. W. (1977). Further paleomagnetic results for the San Juan volcanic field of southern Colorado. Earth Planet. Sci. Lett. 37, 124-130. doi: 10.1016/0012821X(77)90153-4

Bolle, O., Besse, M., and Diot, H. (2010). Magma flow and feeder chamber location inferred from magnetic fabrics in jotunitic dykes (Rodaland anorthosite province, SW Norway). Tectonophysics 493, 42-57. doi: 10.1016/j.tecto.2010.06.017

Day, R., Fuller, M., and Schmidt, V. A. (1977). Hysteresis properties of titanomagnetites: grain-size and compositional dependence. Phys. Earth Planet. Inter. 13, 260-267. doi: 10.1016/0031-9201(77)90108-X

Dunlop, D. J. (2002). Theory and application of the Day plot: 1. Theoretical curves and tests using titanomagnetite data. J. Geophys. Res. 107, 2056. doi: 10.1029/2001JB000486

Ellwood, B. B. (1982). Estimates of flow direction of calc-alkaline welded tuffs and paleomagnetic data reliability from anisotropy of magnetic susceptibility measurements: Central San Juan Mountains, Southwest Colorado. Earth Planet. Sci. Lett. 59, 303-314. doi: 10.1016/0012-821X(82)90133-9

Elston, W. E., and Smith, E. I. (1970). Determination of flow direction of rhyolitic ash flow-tuff from fluidal textures. Geol. Soc. Am. Bull. 81, 3393-3406. doi: 10.1130/0016-7606(1970)81[3393:DOFDOR]2.0.CO;2

Froggatt, P. C., Wilson, C. J. N., and Walker, G. P. L. (1981). Orientation of logs in the Taupo Ignimbrite as indicator of flow direction and vent position. Geology 9, 109-111.

Gee, J. S., Yu, Y., and Bowles, J. (2010). Paleointensity estimates from ignimbrites: an evaluation of the Bishop tuff. Geochem. Geophys. Geosyst. 11, Q03010. doi: $10.1029 / 2009 \mathrm{gc00} 2834$

Geissman, J. W. (1980). Paleomagnetism of ash-flow tuffs: microanalytical recognition of TRM components. J. Geophys. Res. 85, 1487-1499. doi: 10.1029/ JB085iB03p01487

Geissman, J. W., Newberry, N. G., and Peacor, D. R. (1983). Discrete singledomain and pseudo-single-domain titanomagnetite particle in silicic glass of an ash-flow tuff. Can. J. Earth Sci. 20, 334-338. doi: 10.1139/e83-030

Grunder, A. L., Laporte, D., and Druitt, T. H. (2004). Experimental and textural investigation of welding: effects of compaction, sintering, and vapor-phase

\section{FUNDING}

This work was supported by the Polar Academic Program (PD16010), Korea Polar Research Institute, 2016.

\section{ACKNOWLEDGMENTS}

Lae Hee Han and Su Min Lee provided tremendous help in the field.

\section{SUPPLEMENTARY MATERIAL}

The Supplementary Material for this article can be found online at: http://journal.frontiersin.org/article/10.3389/feart. 2016.00079

crystallization in the rhyolitic Rattlesnake Tuff. J. Volcanol. Geotherm. Res. 142, 89-104. doi: 10.1016/j.jvolgeores.2004.10.018

Hatherton, T. (1954). The permanent magnetization of horizontal volcanic sheets. J. Geophys. Res. 59, 223-232. doi: 10.1029/JZ059i002p00223

Hillhouse, J. W., and Wells, R. E. (1991). Magnetic fabric, flow directions, and source data of the lower Miocene Peach Springs tuff in Arizona, California, and Nevada. J. Geophys. Res. 96, 12443-12460.

Jelinek, V. (1976). The statistical theory of measuring anisotropy of magnetic susceptibility of rocks and its application. Geophysika 87, 1-88.

Jelinek, V. (1981). Characterization of the magnetic fabric of rocks. Tectonophysics 79, 63-67. doi: 10.1016/0040-1951(81)90110-4

Jeong, D., Yu, Y., Doh, S. J., Suk, D., and Kim, J. (2015). Paleomagnetism and U$\mathrm{Pb}$ geochronology of the late Cretaceous Chisulryoung Volcanic Formation, Korea: tectonic evolution of the Korean Peninsula. Earth Planets Space 67, 1-14, doi: 10.1186/s40623-015-0242-y

Kamata, H., and Mimura, K. (1983). Flow directions inferred from imbrication in the Handa pyroclastic flow deposit in Japan. Bull. Volcanol. 46, 277-282. doi: 10.1007/BF02597562

Kokelaar, B. P. (1982). Fluidization of wet sediments during the emplacement and cooling of various igneous bodies. J. Geol. Soc. 139, 21-33. doi: 10.1144/gsjgs.139.1.0021

MacDonald, W. D., and Palmer, H. C. (1990). Flow directions in ash-flow tuffs: a comparison of geological and magnetic susceptibility measurements, Tshirege member (upper Bandelier tuff), Valles caldera, New Mexico, USA. Bull. Volcanol. 53, 45-59. doi: 10.1007/BF00680319

Ort, M. H., de Silva, S. L., Jiménez, N., Jicha, B. R., and Singer, B. S. (2013). Correlation of ignimbrites using characteristic remanent magnetization and anisotropy of magnetic susceptibility, Central Andes, Bolivia. Geochem. Geophys. Geosyst. 14, 141-157. doi: 10.1029/2012gc004276

Ort, M. H., Rosi, M., and Anderson, C. D. (1999). Correlation of deposits and vent locations of the proximal Campanian Ignimbrite deposits, Campi Flegrei, Italy, based on NRM and AMS characteristics. J. Volcanol. Geotherm. Res. 91, 167-178. doi: 10.1016/S0377-0273(99)00034-7

Palmer, H. C., and MacDonald, W. D. (1999). Anisotropy of magnetic susceptibility in relation to source vents of ignimbrites: empirical observations. Tectonophysics 307, 207-218. doi: 10.1016/S0040-1951(99)0 0126-2

Palmer, H. C., and MacDonald, W. D. (2002). The Northeast Nevada Volcanic field: magnetic properties and source implications. J. Geophys. Res. 107, 2298. doi: 10.1029/2001jb000690

Palmer, H. C., MacDonald, W. D., Grommé, C. S., and Ellwood, B. B. (1996). Magnetic properties and emplacement of the Bishop tuff, California. Bull. Volcanol. 58, 101-116. doi: 10.1007/s004450050129

Palmer, H. C., MacDonald, W. D., and Hayatsu, A. (1991). Magnetic, structural and geochronologic evidence bearing on volcanic sources and Oligocene deformation of ash flow tuffs, northeast Nevada. J. Geophys. Res. 96, 2185-2202. doi: 10.1029/90JB02224 
Park, K. H. (1990). A down sag caldera associated with the Chisulryoung Volcanic Formation, near Kyeongju city, southern Korea. J. Geol. Soc. Korea 26, 213-216.

Park, K. H., and Kim, S. E. (1985a). Ash-flow tuffs of the Chisulryoung Volcanic Formation and associated welded tuff intrusion, Wolseong District, southern Korea. J. Korean. Inst. Min. 18, 125-134.

Park, K. H., and Kim, S. E. (1985b). A layered felsic diatreme near Wolseong, Geongsang Buk Do, Korea. J. Geol. Soc. Korea 18, 357-368.

Petronis, M. S., and Geissman, J. W. (2009). Anisotropy of magnetic susceptibility data bearing on the transport direction of mid-Tertiary regional ignimbrites, Candelaria Hills area, West-Central Nevada. Bull. Volcanol. 71, 121-151. doi: 10.1007/s00445-008-0212-3

Potter, D. K., and Stephenson, A. (1988). Single-domain particles in rocks and magnetic fabric analysis. Geophys. Res. Lett. 15, 1097-1110. doi: 10.1029/ GL015i010p01097

Reedman, A. J., Park, K. H., and Evans, J. A. (1989). The age of granitoid intrusions and related mineralization in the Chisulryoung mountain area, south-east Korea: constraints on the age of the Chisulryoung Volcanic Formation and Yucheon Group volcanism. J. Geol. Soc. Korea. 25, 51-58.

Reedman, A. J., Park, K. H., Merriman, R. J., and Kim, S. E. (1987). Primary welded tuff infilling a volcanic vent at Weolseong, Republic of Korea. Bull. Volcanol. 49, 541-546. doi: 10.1007/BF01080448

Reynolds, R. L. (1977). Paleomagnetism of welded tuffs of the tuffs of the Yellowstone group. J. Geophys. Res. 82, 3677-3693. doi: 10.1029/JB082i026p 03677

Robion, P., Averbuch, O., and Sintubin, M. (1999). Fabric development and metamorphic evolution of Lower Paleozoic slaty rocks from the Rocroi massif (French-Belgian Ardennnes): new constraints from magnetic fabrics, phyllosilicate preferred orientation and illite crystallinity data. Tectonophysics 309, 257-273. doi: 10.1016/S0040-1951(99)00142-0

Rochette, P. (1988). Inverse magnetic fabric in carbonate-bearing rocks. Earth Planet. Sci. Lett. 90, 229-237. doi: 10.1016/0012-821X(88)90103-3

Rochette, P., Aubourg, C., and Perrin, M. (1999). Is this magnetic fabric normal? A review and case studies in volcanic formations. Tectonophysics 307, 219-234. doi: 10.1016/S0040-1951(99)00127-4

Rochette, P., Jackson, M., and Aubourg, C. (1992). Rock magnetism and the interpretation of the anisotropy of magnetic susceptibility. Rev. Geophys. 30, 209-226. doi: 10.1029/92RG00733

Rosenbaum, J. G. (1993). Magnetic grain-size variations through an ash flow sheet: influence on magnetic properties and implications for cooling history. J. Geophys. Res. 98, 11715-11727. doi: 10.1029/93jb00355

Schlinger, C. M., Griscom, D., Papaefthymiou, G., and Veblen, D. R. (1988b). The nature of magnetic single-domains in volcanic glasses of the KBS tuff. J. Geophys. Res. 93, 9137-9156. doi: 10.1029/JB093iB08p09137
Schlinger, C. M., Rosenbaum, J. G., and Veblen, D. R. (1988a). Fe-oxide microcrystals in welded tuff from southern Nevada: origin of remanence carriers by precipitation in volcanic glass. Geology 16, 556-559.

Schlinger, C. M., Smith, R. M., and Veblen, D. R. (1986). Geologic origin of magnetic volcanic glasses in the KBS tuff. Geology 14, 959-962.

Schlinger, C. M., Veblen, D. R., and Rosenbaum, J. G. (1991). Magnetism and magnetic mineralogy of ash flow tuffs from Yucca Mountain, Nevada. J. Geophys. Res. 96, 6035-6052. doi: 10.1029/90JB02653

Suzuki, K., and Ui, T. (1982). Grain orientation and depositional ramps as flow direction indicators of large-scale pyroclastic flow deposits, Japan. Geology 10, $429-432$.

Suzuki, K., and Ui, T. (1983). Factors governing the flow lineation of a large-scale pyroclastic flow: an example in the Ata pyroclastic flow deposit, Japan. Bull. Volcanol. 46, 71-81. doi: 10.1007/BF02598246

Tauxe, L. (2010). Essentials of Paleomagnetism. Berkely, CA: University of California Press.

Trindade, R. I. F., Raposo, M. I. B., Ernesto, M., and Siqueira, R. (1999). Magnetic susceptibility and partial anysteretic remanence anisotropies in the magnetitebearing granite pluton of Tourao, NE Brazil. Tectonophysics 314, 443-468. doi: 10.1016/S0040-1951(99)00220-6

Werner, T., and Borradaile, G. J. (1996). Paleoremanence dispersal across a transpressed Archean terrain: deflection by anisotropy or by late compression? J. Geophys. Res. 101, 5531-5545. doi: 10.1029/95jb03047

Wolff, J. A., Ellwood, B. B., and Sachs, S. D. (1989). Anisotropy of magnetic susceptibility in welded tuffs: application to a welded-tuff dike in the Tertiary Trans-Pecos Texas volcanic province, USA. Bull. Volcanol. 51, 299-310. doi: 10.1007/BF01073518

Wolff, J. A., and Wright, J. V. (1991). Rheomorphism of welded tuffs. J. Volcanol. Geotherm. Res. 10, 13-34. doi: 10.1016/0377-0273(81)90052-4

Worm, H. U., and Jackson, M. (1999). The superparamagnetism of Yucca Mountain Tuff. J. Geophys. Res. 104, 25415-25425. doi: 10.1029/1999jb9 00285

Conflict of Interest Statement: The authors declare that the research was conducted in the absence of any commercial or financial relationships that could be construed as a potential conflict of interest.

Copyright (c) 2016 Hong, Yu, Doh, Suk and Kim. This is an open-access article distributed under the terms of the Creative Commons Attribution License (CC BY). The use, distribution or reproduction in other forums is permitted, provided the original author(s) or licensor are credited and that the original publication in this journal is cited, in accordance with accepted academic practice. No use, distribution or reproduction is permitted which does not comply with these terms. 